\title{
Growth Characteristics of Six Reciprocal Crosses of Kenyan Indigenous Chicken
}

\author{
J. M. Ndegwa (Corresponding author), R. Mead, P. Norrish \& D. D. Shephered \\ The University of Reading, Department of Applied Statistics and International and Rural Development \\ Department(IRDD), PO Box Earley Gate, RG6 6FN, Reading, UK \\ E-mail: j.n.ndegwa@reading.ac.uk \\ C. W. Kimani \& A. M. Wachira \\ Kenya Agricultural Research Institute, National Animal Husbandry Research Centre \\ PO Box 25, Naivasha, Kenya
}

Received: January 10, 2012 Accepted: February 6, 2012 Online Published: April 20, 2012

doi:10.5539/jas.v4n6p160

URL: http://dx.doi.org/10.5539/jas.v4n6p160

\begin{abstract}
A study was carried out at the poultry research unit of the Kenya Agricultural Research Institute, National Animal Husbandry Research Centre, Naivasha in 1993 and 1994, to investigate growth performance of six reciprocal crosses of indigenous chicken originating from the Taita, Nyeri and Kericho districts in Kenya. Six hundred mixed sex day old chicks were used. Feed and water were provided ad libitum and the birds weighed individually on weekly basis up to the age of 30 weeks. Non-linear regression model procedures of the statistical analysis system (SAS) were used in data analysis. The gompertz growth model was used in fitting the body weight data with three parameter estimates, A, B and K. A statistical analysis of residual variations was used to determine differences between fitted curves. There were significant differences in growth pattern among the reciprocal crosses of indigenous chicken and between male and female birds. There was a possible effect of the choice of dam or sire in a given combination. The Nyeri line seemed to perform potentially better as a dam for both male and female offspring. The Taita line on the other hand, seemed to potentially perform better as a sire and so was the Kericho line. Use of growth data beyond 20 weeks resulted in better expression of asymptotic nature of fitted curves. There is some potential for improvement of the performance among indigenous flocks by judicious cross breeding strategies.
\end{abstract}

Keywords: Kenya, Indigenous chicken, Growth characteristics, Reciprocal crossing

\section{Introduction}

Indigenous chicken, reared extensively by rural households, are characterised by low productivity in terms of meat and eggs (Stotz, 1983). This is attributed mainly to poor feeding and management regime and low genetic potential (Ndegwa, et. al., 1998; Ndegwa and Kimani, 1996; Musharaf, 1990; Musharaf et al., 1990; Provost et al., 1990). However, lack of data on genetic parameters has militated against their development and characterisation as breeds. Despite the low productivity with all the attendant constraints, indigenous chicken produce more than $50 \%$ of total eggs and $70 \%$ of poultry meat in Kenya (MOALD \& M, 1993). Over 70\% of the human population in Kenya and other sub-Saharan African countries live in rural areas (Stotz, 1983; Ibe, 1990; Ndegwa et. al., 1998) hence, there exists a potential for indigenous chicken to supply much of the required animal protein. It is estimated that $90 \%$ of rural households keep indigenous chicken often in flocks of $10-20$ birds (Mbugua, 1990; MOLD, 1990; Ndegwa et. al., 1999;) Indigenous meat and eggs are more preferred and often do fetch higher prices than the exotic commercial poultry products. As reported by Ndegwa et. al., (1998), its delicious taste, texture of carcass, little fat content and flavour make indigenous poultry meat a highly appreciated and marketable product. Eggs from indigenous birds are similarly preferred due to their taste and colour of yolk. 
Rearing of indigenous birds is mainly by women all over sub-Saharan Africa, as it is lowly rated in terms of its importance in the farming system. It provides an area for rural women to generate some income. Indigenous chicken production should therefore be improved as a strategy to empower the rural women who mainly bear the effects of the extreme poverty prevailing all over the sub-Saharan Africa region.

The flock is mostly unimproved although efforts had been made by the National Poultry Development Project (NPDP) of the Ministry of Agriculture and Livestock Development (MoALD, 1993), to improve the local chicken through cockerel exchange programmes in twenty-six districts in Kenya. Egg-type hybrids and pure breed Rhode Island Red chickens were used. The genetic and economic impact of this exercise has not been rigorously quantified. Besides, this attempt at crossbreeding was unplanned and did not aim at first establishing the genetic merit of the local chicken using clearly defined genetic indicators, such as heritability and correlation. Further, little efforts have so far been made to characterise the indigenous chicken in Kenya.

Planned improvement of local chicken in Nigeria was found to be appreciably improved by crossbreeding rather than selective breeding, (Oluyemi, 1979). Similar observations were made by Asiedu \& Weaver, (1993). Crossbreeding has been a major tool for the development of present day commercial breeds of chickens (Sheridan, 1981) and could likewise be used to improve the local chicken.

The aim of this study was to investigate and compare the growth performance of reciprocal crosses of indigenous chicken originating from the Taita, Nyeri and Kericho districts in Kenya as an attempt at generating information about the birds for use in research and development strategies to improve productivity.

\section{Materials and Method}

Six hundred mixed sex day old reciprocal crossbred indigenous chicks were used in this study that was carried out at the poultry research unit of the Kenya Agricultural Research Institute, National Animal Husbandry Research Centre, Naivasha in 1993 and 1994. The crosses were from three lines of indigenous chicken originating from the Nyeri, Kericho and Taita districts in Kenya and all possible crosses were made. These districts are far removed from each other with distinct agro-climatic conditions. Taita is located in the coastal region of the country and is low in altitude and relatively dry. Nyeri is in the central highlands and has a wet climate as a result of the seasonal movement of the Inter Tropical Convergence Zone (ITCZ) and the influence of local geographical factors. It has good and well-drained soils. Kericho lies in the western region of the country and is also wet and has good soils. This region is wet throughout the year, mainly because of the moisture influx from Lake Victoria.

The resulting six crosses were, Nyeri*Kericho (NK), Kericho*Nyeri (KN), Nyeri*Taita (NT), Taita*Nyeri (TN), Kericho*Taita (KT), and Taita*Kericho (TK). The first in the combination is the male.

The crossbred chicks were from eggs laid and hatched at the research unit in a 'Comfort' model hatchery and wing bands placed on each chick for identification. They were raised from day-old to 30 weeks of age in a deep litter (wood shavings) production system. Brooding was on the floor using 250 watts bulbs. The chicks were raised on a standard rearing ration containing $18 \%$ crude protein and $2800 \mathrm{Kcal}$ per kg feed (Table1). Feed and water were provided ad libitum.

Body weights were taken at hatch and subsequently on weekly basis for each individual chick.

\section{Statistical analysis}

Statistical analysis of the data involved use of non-linear regression model procedures (nlin), of the Statistical Analysis System (SAS, 1985). The Gompertz growth model was chosen to fit the data on body weights, as described in literature by various authors (Brody, 1945; Bertalanffy, 1960; Wilson, 1977; Causton, 1983; Adam et al., 1988; Ratkowsky,1989; Brown and Rothery, 1993; Lawrence \& Fowler, 1997;). The growth model had been found to meet convergence criterion both in this and an earlier study with individual lines (Ndegwa et. al., 2005).

The gompertz log-form model $\left(\log w=\log a-b^{*} \exp \left(-\mathrm{k}^{*} \mathrm{t}\right)\right.$ was used in the regression, where $\mathrm{w}$ is the measured weight that was related to age $t$, in weeks. The three parameters in the model, a, $\mathrm{b}$ and $\mathrm{k}$ were obtained by a least-square fit to the data. Parameter a, is the asymptote to which growth curve i.e. size of the bird tends. Both $b$ and $k$ are constants of relative growth rate $(\mathrm{R}=\mathrm{kbexp}-\mathrm{k} * \mathrm{t}=\mathrm{kloga}-\mathrm{klogy})$. Logarithm of relative growth rate $\mathrm{R}$, is a linear function of time with gradient $-\mathrm{k}$ and intercept $\log (\mathrm{k} * \mathrm{~b})$. $\mathrm{R}$ is also a linear function of the logarithm of size, with gradient $-\mathrm{k}$ and intercept kloga. The initial parameter estimates were $\mathrm{a}=2500, \mathrm{~b}=4.5$ and $\mathrm{k}=0.1$ as described by Ndegwa et. al. (2005) 
Differences between the fitted curves for the six reciprocal crosses were evaluated by analysis of residual variations similar to the one described by Mead et. al., (1993).

\section{Results and Discussion}

In table 2 are shown regression equations relating the weight of male and female birds to time from hatching in the six reciprocal crosses of indigenous chicken. Figure 1 on the other hand, shows mean weight trends of male and female birds. In all the six crosses a similar pattern emerged where body weights of both the male and female birds were indistinguishable in the early stages of growth up to around the $10^{\text {th }}$ week of age. Thereafter, male birds outgrew their female siblings quite fast in terms of body weight gain. This would be brought about by a differential change in hormonal activity between the two sexes around this point in their growth stage as the birds get to sexual maturity.

For the male birds, the asymptotic weight values A, of the six crosses ranged from 3002 to $2610 \mathrm{~g}$. Asymptotic weights of the female birds were lower at the range of 1738 to $2153 \mathrm{~g}$., a similar range as that of the male birds. The Taita*Nyeri crosses had the highest A values among the male birds while in the case of females, the Nyeri*Taita crosses had the highest A values. The difference between asymptotic weight for males and for females ranges from 549 (Nyeri*Taita) to 989 (Taita*Nyeri). There seems to be an interesting 'mix' of genes in the various combinations resulting in heaviest male birds being of a different though similar combination to that of heaviest female birds. The male birds are heaviest when the Taita line is the sire, but for the heaviest female birds, it is when Taita line is the dam. In an earlier study with pure lines, among the male birds, Nyeri were the heaviest followed by Taita while in case of the female birds, Nyeri and Kericho were the heaviest in that order (Ndegwa et. al., 2005).

The range of parameter B was from 4.191 to 4.457 and from 3.853 to 4.073 in the male and female birds respectively. As in the case of parameter A values, these too were higher in the male than in the female birds. For the $\mathrm{K}$ values, they ranged from 0.1125 to 0.1315 and from 0.1157 to 0.1355 for male and female birds respectively - a reversed trend. As mentioned elsewhere by Ndegwa et. al., (2005), the larger the K value, the shorter the period taken to reach final weight A. The male birds continued growing long after their female siblings got to their peak. In other words female birds matured earlier than the male birds and this has an implication in their management practices due to obvious differential nutrient and behavioural requirements at such a point in the growth curve.

In all the six reciprocal crosses (Figure 1), both male and female birds exhibited a similar growth pattern difficulty to discern during the early weeks in the growth period before the $10^{\text {th }}$ week of age. The pattern was much the same as that noted in the earlier study by Ndegwa et. al., (Unpublished). The observed mean body weight at 6 weeks of age was $342 \pm 14$ and $304 \pm 12 \mathrm{~g}$ for male and female birds respectively. Beyond the $10^{\text {th }}$ week of age, there were clear differences in body weights discernible from the plots and the observed values shown in figure 1 and table 5 . The observed mean body weight at 18 weeks of age was $1691 \pm 46 \mathrm{~g}$ and $1261 \pm 26$ $\mathrm{g}$ for male and female birds respectively. Sexing of the birds using physical features was therefore only possible beyond week ten.

From the information given in table 2 and looking at figures I and II, it seems the differences in the regression parameters $\mathrm{A}, \mathrm{B}$ and $\mathrm{K}$, contribute more to the differences in the fitted curves among the six crosses. These differences are presented more formally by use of an analysis of residual variation described by Mead et al., (1993) whose details are shown in table 3. A comparison is made between fitting separate curves for the six crosses and fitting a single curve to the combined data set. The sum of squared residuals for the single fitted curve, is much larger than the sum of squared residuals for the separate curves. Difference between the residual sum of squares for the two models are assessed by an F-test giving F statistics of 42.0 and 40.38 for male and female birds respectively on 15 and 156 degrees of freedom. The F statistics is clearly very highly significant. Hence the data of the six crosses cannot be summarised in a single fitted curve for either sex.

Table 4 shows significance level of comparison with similar analysis as the above for all possible combinations. They were all significant $(\mathrm{p}<0.05)$ except for comparison between Nyeri*Kericho and Nyeri*Taita male birds. The Nyeri male line seems to exert a similar and dominant influence on the other two lines for the male offspring.

Tables 5 and 6 show detailed analysis of growth patterns in terms of asymptotic, final or mature body weight A, initial body weight, constant of rate of approach to mature weight $\mathrm{K}$, maximum growth rate and half growth time of male and female birds. Initial weight ranged from 33 to $42 \mathrm{~g}$ and from 33 to $43 \mathrm{~g}$ in male and female birds respectively. These figures are similar to those from the earlier study by Ndegwa et al., (2005) involving individual lines although the former are just slightly higher than the latter. As was the case in the earlier study, 
the variation is small but appear to be correlated with final weight. Maximum growth rate, $\mathrm{K}^{*} \mathrm{~A} 0.368$ (Brown and Rothery, 1993) of all the six crosses of indigenous chicken was in the range of 115 to 135 and 87 to $98 \mathrm{~g}$. per week in male and female birds respectively. These figures are close to, though slightly lower than those of the individual lines of indigenous chicken shown in the study by Ndegwa et al. (2005) which was in the range of 140 to 155 and 90 to $100 \mathrm{~g}$ per bird per week, in male and female birds respectively.

The $\mathrm{K}$ values fluctuated within and between the sexes and ranged from 0.1125 to 0.1315 and from 0.1157 to 0.1355 in male and female birds respectively. These values influenced the values of half growth time and which ranged from 13.6 to 16.1 weeks and from 12.8 to 15.3 weeks in male and female birds respectively in all the six crosses. As was the case in the earlier study with the individual lines, the female crosses took shorter time to mature although at a less final weight than the male birds.

From the fitted curves and residuals analysis, an indication is given of a significant difference in growth pattern among the six crosses for both male and female birds. For the male birds, Taita*Nyeri crosses had the highest maximum weight while in female birds, it was Nyeri*Taita crosses. The Kericho*Taita crosses had the lowest maximum weight in both the male and female birds. It mattered which line of indigenous chicken was used as dam and which as sire in a particular combination of the offspring in both male and female birds. Generally, the Nyeri line seems to perform potentially better when used as dam in male and female offspring when all the parameters defining their growth are taken into account. The Taita line seems to potentially perform well when used as sire in both male and female offspring. Kericho line also seems to potentially perform better in both male and female offspring when used as sire. These observations would definitely have implications in genetic improvement strategies of indigenous chicken and should be taken into account when designing such strategies.

The asymptotic nature of the fitted curves for the six crosses is better expressed than was the case in the earlier study with individual lines where the data used was only for up to 20 weeks of age, a time when the birds were still growing hence affecting prediction. In the present study, data used was for a longer period extending to 30 weeks of age and hence an improvement in prediction as seen from the fitted curves.

The observed and predicted mean body weights at 18 weeks of age are shown in table 7 . In male chicken, they ranged from 1580 to 1890 and from 1530 to $1860 \mathrm{~g}$ for predicted and observed weights respectively. In case of the female birds, the range was from 1220 to 1410 and from 1180 to $1360 \mathrm{~g}$ for predicted and observed weights respectively. These figures are higher than those reported in an earlier study for individual lines but in both cases, there was a larger variation among male birds than in the female birds. There seem to be an effect of hybrid vigour as a result of crossing between different indigenous chicken lines. The Kericho*Nyeri cross had the highest body weight values at this point and also highest maximum growth rate for both male and female birds. Its half growth time in both sexes was also among the shortest at 13 weeks. On the other had, the Taita*Kericho cross, had the least body weight value at 18 weeks with lowest maximum growth rate as well as longest half growth time of the female birds. For the male birds, the least body weight value was shown by the Nyeri*Kericho cross. But this trend would change with time.

\section{Conclusions}

The results of this study help to shed more light into the growth characteristics of indigenous chicken and should be used for further research geared towards improvement of their production performance for the benefits rural farmers who main rear the birds. If birds are adequately fed, one can easily plan for instance, when to market them to raise cash for specific household needs such as paying for school fees. Research should focus on improvement of growth parameters such as reducing the half-growth time and increasing asymptotic weights without increasing cost of production.

Cross breeding of the indigenous chickens among themselves was an important step towards more and meaningful utilisation of local indigenous resources so abundant in rural areas as one strategy towards poverty alleviation among the populace. There was an improvement in growth performance of the crosses compared to that of individual lines. This lead should be taken up by research and development agencies to set up more vigorous breeding strategies that will conserve and raise production potential of this important but often neglected local resource of the rural poor.

Based on the fitted curves and the asymptotic or maximum (potential) weight, there were significant effect between reciprocal crosses and among the six crosses of indigenous chicken. From the results of this study, it seems to matter which line of indigenous chicken is used as dam or sire to obtain best performance of either male or female offspring. These observations should be put into account in future research and development breeding strategies for improvement of indigenous chicken. 
There is some potential for improving performance of indigenous chicken through judiciously applied cross breeding strategies among indigenous flocks.

While the regression procedures used in this study are similar to those used in an earlier study involving individual lines of indigenous chicken, in the present study, the fitting was smoother with obvious asymptotes. This could have arisen out of the differences in length of study period between the two. It was 20 and 30 weeks in the first and second study respectively. Future research work using growth models and statistical techniques highlighted in this study should always take cognisance of this observation to minimise residual sums of squares and obtain a good fit with clear asymptotes.

As it was the case with the analysis of growth parameters of individual lines of indigenous chicken, the use of growth model in this study was also very hardy and it simplified statistical analysis of enormous amount of data collected regularly over a long period. Much of the data would not have been used in the analysis without such statistical tools and this would have given a less accurate picture of the growth pattern.

\section{Acknowledgement}

The authors wish to thank the Director KARI, the Centre Director, National Animal Husbandry Research Centre, Naivasha, Kenya and the Royal Netherlands Government, for their support, financial and otherwise. Special thanks and gratitude go to the staff of the Poultry Research Unit, Naivasha and the statistical computing personnel at the department of Applied Statistics, University of Reading, UK, for their tireless assistance.

\section{References}

Bertalanffy, L. von. (1960). Principles and theory of growth. In: Wiktor, W. N. Fundamental aspects of normal and malignant growth. Elsevier.

Brody, S. (1945). Bioenergetics and Growth. Hafner, New York.

Brown, D., \& Rotherly, P. (1993). Models in Biology: Mathematics, Statistics and Computing. John Wiley \& Sons Ltd, England.

Causton, D. R. (1983). A Biologist's Basic Mathematics. Edward Arnold (Publishers) Ltd.

Lawrence, T. L. J., \& Fowler, V. R. (1997). Growth of farm animals. CAB International.

Mbugua, P. N., (1990). Rural smallholder poultry production in Kenya. In Proceedings of A seminar on Smallholder Rural Poultry Production 9 - 10th October 1990 (pp. 113-115). Thessaloniki, Greece. FAO, Rome.

Mead, R. Curnow, R. N., \& Hasted, A. M. (1993). Statistical Methods in Agriculture and Experimental Biology. $2^{\text {nd }}$ Ed. Chapman and Hall. England.

MoALD \& M, (1993). Ministry of Agriculture, Livestock Development and Marketing, Annual Report.

MOLD. (1990). Ministry of Livestock Development, Annual Report.

Musharaf, A. N. (1990). Rural poultry production in Sudan. Proceedings of International workshop on Rural Poultry Development in Africa. Obafemi Awolowo Univ. Ile - Ife Nigeria.

Musharaf, N. A., Mbugua, P. N., \& Zubeir, El, E. A. (1990). Feeding and Feed Resources, (WG3), CTA seminar proceedings on smallholder rural poultry production, 9-13 October, Thessaloniki Greece, 1, 17-19.

Ndegwa, J. M., \& Kimani, C. W., (1996). Rural poultry production in Kenya: Research and development strategies. In: Proceedings of $5^{\text {th }}$ Kenya Agricultural Research Institute (KARI) scientific conference, October 1996. KARI, Nairobi.

Ndegwa, J. M., Kimani. C. W., Siamba, D. N., Mukisira, E. A., \& De Jong R. (1999). Characteristics of Rural poultry production in different agro-ecological zones in Nakuru, Nyandarua and Laikipia districts of Kenya. In: Proceedings of $6^{\text {th }}$ Kenya Agricultural Research Institute scientific conference, 9-13 November 1998, pp 540 -547. KARI, Nairobi.

Ndegwa, J. M., Tchombe, T., Kabuage, L. W., Mukkibi-Muka, G., \& Kosgey I. S. (1998). Improvement of indigenous poultry production in Sub-Saharan Africa. A paper presented at the International Course on Intensive Poultry Production held at the Centre for International Agricultural Development Co-operation (CINADCO). Kibbutz Shefayim, 4 March - 1 April 1998. P.O. Box 7011, Tel-Aviv, Israel.

Ndegwa, J. M., Mead, R., Norrish, P., Shephered, D. D., Kimani, C. W., \& Wachira, A. (2005). Growth characteristics of indigenous chicken lines and a cross with Rhode Island Red in Kenya. Trop. Agric. (Trinidad), $82(1), 51-58$. 
Oluyemi, J. A. (1979). Selection of indigenous fowl for 12 week body weight. Nig. J. Anim Prod., 6(122), 15-20.

Provost, A. Horst, P., \& Bell J. G. (1990). Breeding and reproduction (WG.1) and Husbandry Health and Hygiene (WG2), CTA - seminar proceedings on smallholder rural poultry production, 9-13 October, Thessaloniki Greece, 1, 11-13.

Ratkowsky, D. A. (1989). Handbook of nonlinear regression models. Marcel Dekker, INC. New York and Basel.

SAS. (1985). SAS Users' Guide: Statistics, version 5 edition. pp. 575-606.

Sheridan, A. K. (1981). Cross breeding and Heterosis. Animal Breeding Abstracts, 19(3), 131-144.

Stotz, D. (1983). Production techniques and economics of small holders livestock production systems in Kenya. In: Farm management handbook of Kenya, 4, pp. 95-106.

Wilson, B. J. (1977). Growth curves: Their analysis and use. In: Boorman, K. N. Growth and Poultry production, (pp. 89-115). British Poultry science Ltd, Edinburgh.

Table 1. Diet composition

\begin{tabular}{lc}
\hline Ingredient & $\%$ \\
\hline White maize & 35.8 \\
Wheat meal & 38.0 \\
Sunflower cake & 3.0 \\
Soya cake & 18.5 \\
dl - Methionine & 0.25 \\
Mineral/vitamin premix & 0.25 \\
Salt & 0.30 \\
Anticoccidiol & 0.10 \\
Calculated analysis: & \\
ME, (kcal/kg) & 2800 \\
Crude protein, (\%) & 18 \\
\hline
\end{tabular}

Table 2. Regression equations relating log body weight in grams of indigenous chicken reciprocal crosses to time in weeks of growth from hatching

\begin{tabular}{lll}
\hline $\begin{array}{l}\text { Dependent variable } \\
\text { Log(mean weight, } g)\end{array}$ & \multicolumn{2}{c}{ Regression function } \\
\hline & Male & Female \\
Nyeri*Kericho & $\log 2796-4.257 * \exp (-0.1125 \mathrm{t})$ & $\log 2031-3.954^{*} \exp (-0.1183 \mathrm{t})$ \\
Kericho*Nyeri & $\log 2795-4.191 * \exp (-0.1315 \mathrm{t})$ & $\log 2022-3.853 * \exp (-0.1313 \mathrm{t})$ \\
Nyeri*Taita & $\log 2702-4.307 * \exp (-0.1161 \mathrm{t})$ & $\log 2153-4.137 * \exp (-0.1177 \mathrm{t})$ \\
Taita*Nyeri & $\log 3002-4.325 * \exp (-0.1172 \mathrm{t})$ & $\log 2013-3.928 * \exp (-0.1253 \mathrm{t})$ \\
Kericho*Taita & $\log 2610-4.338 * \exp (-0.1288 \mathrm{t})$ & $\log 1738-3.967 * \exp (-0.1355 \mathrm{t})$ \\
Taita*Kericho & $\log 2860-4.457 * \exp (-0.1164 \mathrm{t})$ & $\log 2040-4.073 * \exp (-0.1157 \mathrm{t})$ \\
\hline
\end{tabular}

Table 3. Analysis of residuals sums of squares with degrees of freedom, mean squares and F-ratios for comparison of common curve model with separate curve models for six reciprocal crosses of indigenous chicken

\begin{tabular}{lllll}
\hline Model & RSS & DF & MS & F \\
Males & & & & \\
1. Separate curves & 0.2521 & 156 & 0.0016 & \\
2. Difference (3)-(1) & 1.0079 & 15 & 0.0672 & $0.0672 / 0.0016=42\left(\mathrm{~F}_{15,156}\right)=1.22$ \\
$\begin{array}{l}\text { 3. Common curve } \\
\text { Female }\end{array}$ & 1.260 & 171 & & \\
$\begin{array}{l}\text { 1. Separate curves } \\
\text { 2. Difference (3)-(1) }\end{array}$ & 0.2026 & 156 & 0.0013 & \\
3. Common curve & 0.787 & 15 & 0.0525 & $0.0525 / 0.0013=40.38\left(\mathrm{~F}_{15,156}\right)=1.22$ \\
\hline
\end{tabular}


Table 4. Significance ${ }^{1}$ of comparison between separate and combined equations of reciprocally crossed indigenous chicken at $5 \%$ level

\begin{tabular}{lcc}
\hline Cross & Male & Female \\
\hline & & \\
All & Yes & Yes \\
Nyeri*Kericho vs Kericho*Nyeri & Yes & Yes \\
Nyeri*Taita vs Taita*Nyeri & Yes & Yes \\
Kericho*Taita vs Taita*Kericho & Yes & Yes \\
Nyeri*Kericho vs Nyeri*Taita & Ns & Yes \\
Kericho*Nyeri vs Taita*Nyeri & Yes & Yes \\
Kericho*Nyeri vs Kericho*Taita & Yes & Yes \\
Nyeri*Kericho vs Taita*Kericho & Yes & Yes \\
Taita*Nyeri vs Taita*Kericho & Yes & Yes \\
Nyeri*Taita vs Kericho*Taita & Yes & Yes \\
\hline
\end{tabular}

1: $\mathrm{ns}=$ no significance difference; yes $=$ significant difference

Table 5. The asymptotic (final or mature) weight $\mathrm{A}$, in $\mathrm{g}$., log of, and, initial weight in $\mathrm{g}$, constant $(\mathrm{K})$ of rate of approach to A, maximum growth rate in $\mathrm{g} /$ week and half growth time in weeks, of indigenous chicken male reciprocal crosses

\begin{tabular}{|c|c|c|c|c|c|c|}
\hline Cross & $\begin{array}{l}\text { Final } \\
\text { weight } \\
\text { A, g. }\end{array}$ & $\begin{array}{l}\log (\text { Initial } \\
\text { weight) }= \\
\log \mathrm{A}-\mathrm{B}\end{array}$ & $\begin{array}{l}\text { Initial } \\
\text { weight, } \\
\text { g. }\end{array}$ & $\begin{array}{l}\mathrm{K} \text {, constant } \\
\text { of rate of } \\
\text { approach to } \\
\text { A }\end{array}$ & $\begin{array}{l}\text { Maximum } \\
\text { Growth rate= } \\
\mathrm{K}^{*} \mathrm{~A} 0.368 \\
\text { g/week }\end{array}$ & $\begin{array}{l}{ }^{1 / 2} \text { Growthtime, } \\
\mathrm{t}_{1 / 2}=(\log \mathrm{B}-\log 0.6932) / \mathrm{K} \\
\text { weeks }\end{array}$ \\
\hline Nyeri*Kericho & 2796 & 3.68 & 39.6 & 0.1125 & 116 & 16.13 \\
\hline Kericho*Nyeri & 2795 & 3.74 & 42.3 & 0.1315 & 135 & 13.68 \\
\hline Nyeri*Taita & 2702 & 3.59 & 36.4 & 0.1161 & 115 & 15.73 \\
\hline Taita*Nyeri & 3002 & 3.68 & 39.7 & 0.1172 & 129 & 15.62 \\
\hline Kericho*Taita & 2610 & 3.53 & 34.1 & 0.1288 & 124 & 14.24 \\
\hline Taita*Kericho & 2860 & 3.50 & 33.2 & 0.1164 & 123 & 15.99 \\
\hline
\end{tabular}

Table 6. The asymptotic (final or mature) weight A, in g., log of, and, initial weight in g., constant (K) of rate of approach to A, maximum growth rate in $\mathrm{g} /$ week and half growth time in weeks, of indigenous chicken female reciprocal crosses

\begin{tabular}{lllllll}
\hline Cross & $\begin{array}{l}\text { Final } \\
\text { weight } \\
\text { A, g. }\end{array}$ & $\begin{array}{l}\mathrm{Log}(\text { Initial } \\
\text { weight }) \\
\operatorname{logA-B}\end{array}$ & $\begin{array}{l}\text { Initial } \\
\text { weight, } \\
\text { g. }\end{array}$ & $\begin{array}{l}\mathrm{K}, \text { constant } \\
\text { of rate of } \\
\text { approach to } \\
\mathrm{A}\end{array}$ & $\begin{array}{l}\text { Maximum } \\
\text { Growth } \\
\text { rate }= \\
\mathrm{K} * \mathrm{~A} 0.368 \\
\mathrm{~g} / \text { week }\end{array}$ & $\begin{array}{l}{ }^{1 / 2} \text { Growthtime, } \\
\mathrm{t}_{1 / 2}=(\operatorname{logB}-\log 0.6932) / \mathrm{K} \\
\text { weeks }\end{array}$ \\
\hline Nyeri*Kericho & 2031 & 3.66 & 39.0 & 0.1183 & 88 & 14.72 \\
Kericho*Nyeri & 2022 & 3.76 & 42.9 & 0.1313 & 98 & 13.06 \\
Nyeri*Taita & 2153 & 3.54 & 34.4 & 0.1177 & 93 & 15.18 \\
Taita*Nyeri & 2013 & 3.68 & 39.6 & 0.1253 & 93 & 13.84 \\
Kericho*Taita & 1738 & 3.49 & 32.9 & 0.1355 & 87 & 12.87 \\
Taita*Kericho & 2040 & 3.55 & 34.7 & 0.1157 & 87 & 15.31 \\
\hline
\end{tabular}


Table 7. Observed and predicted mean body weight $(\mathrm{g})$ of the indigenous chicken crosses at 18 weeks of age

\begin{tabular}{|c|c|c|c|c|c|c|}
\hline \multirow[t]{2}{*}{ Cross } & \multicolumn{3}{|l|}{ Male } & \multicolumn{3}{|l|}{ Female } \\
\hline & $\begin{array}{l}\text { Predicted mean } \\
\text { weight }\end{array}$ & $\begin{array}{l}\text { Observed } \\
\text { Mean } \\
\text { weight }\end{array}$ & $\begin{array}{l}\text { Standard } \\
\text { error= } \\
\mathrm{Sd} / \text { sqrtN }\end{array}$ & $\begin{array}{l}\text { Predicted mean } \\
\text { weight }\end{array}$ & $\begin{array}{l}\text { Observed } \\
\text { Mean } \\
\text { weight }\end{array}$ & $\begin{array}{l}\text { Standard } \\
\text { error }\end{array}$ \\
\hline Nyeri*Kericho & 1594 & 1531 & 35.3 & 1269 & 1232 & 20.9 \\
\hline Kericho*Nyeri & 1886 & 1858 & 31.4 & 1405 & 1361 & 25.7 \\
\hline Nyeri*Taita & 1586 & 1586 & 29.8 & 1310 & 1296 & 27.7 \\
\hline Taita*Nyeri & 1765 & 1783 & 29.9 & 1324 & 1297 & 19.2 \\
\hline Kericho*Taita & 1701 & 1729 & 39.1 & 1229 & 1196 & 22.3 \\
\hline Taita*Kericho & 1652 & 1660 & 61.7 & 1226 & 1182 & 54.8 \\
\hline
\end{tabular}

Observed and fitted mean body weight of NyeriXKericho cross

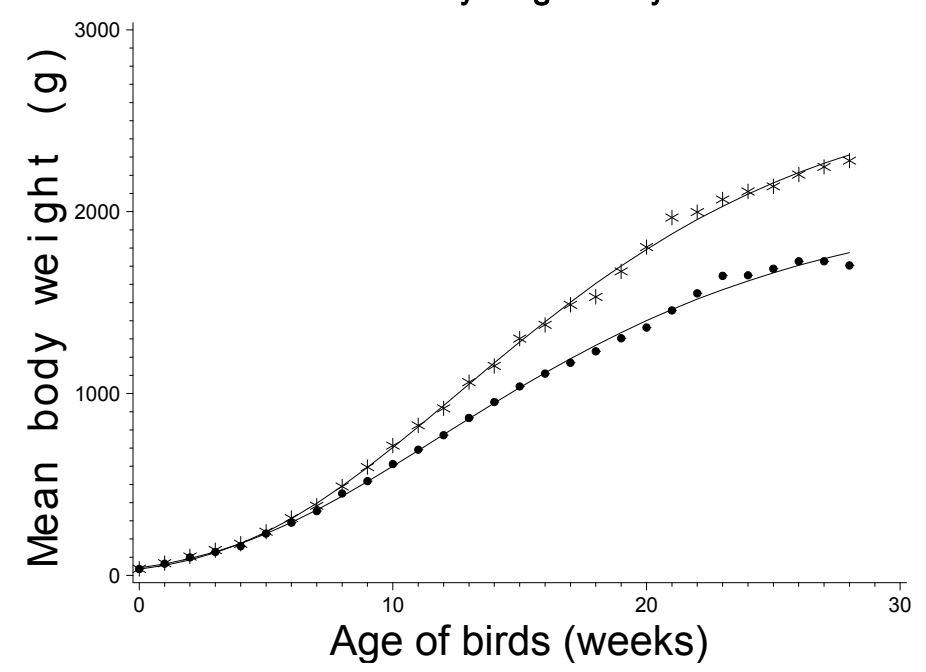

Figure 1a.

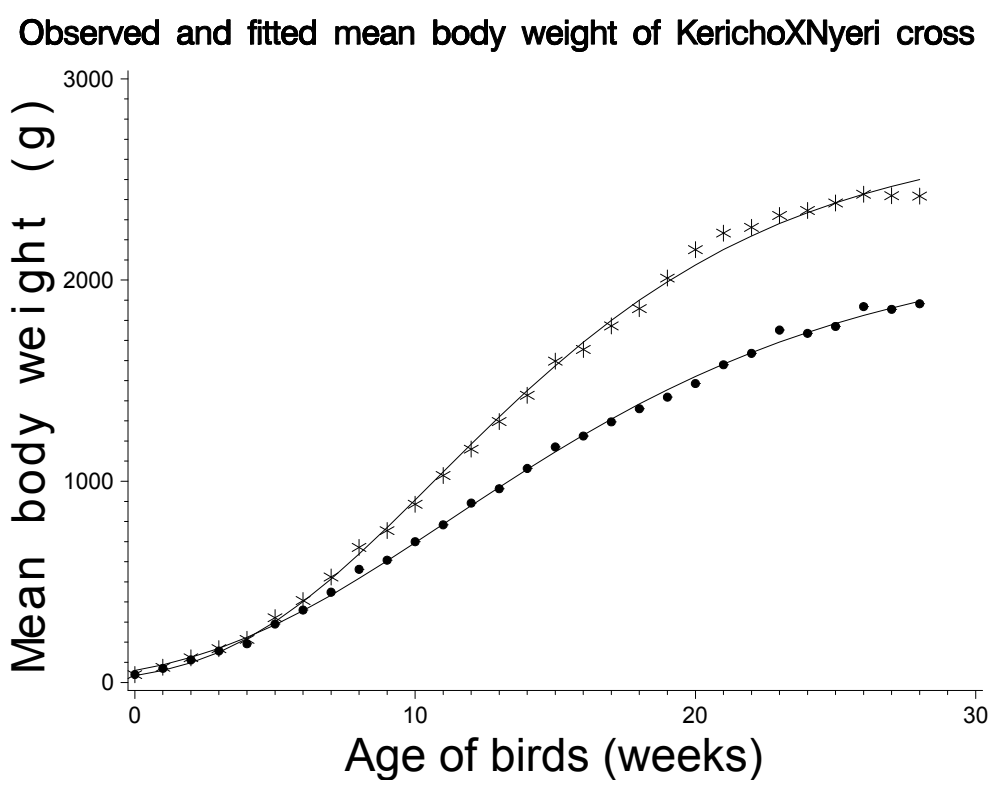

Figure 1b. 
Observed and fitted mean body weight of NyeriXTaita cross

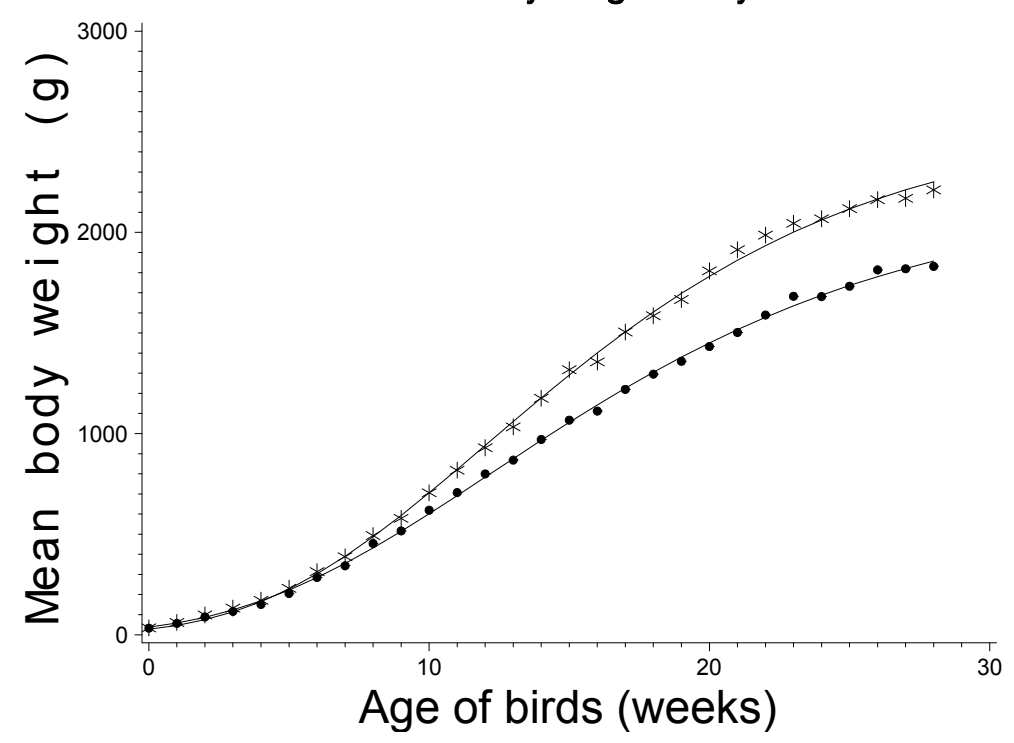

Figure 1c.

Observed and fitted mean body weight of TaitaXNyeri cross

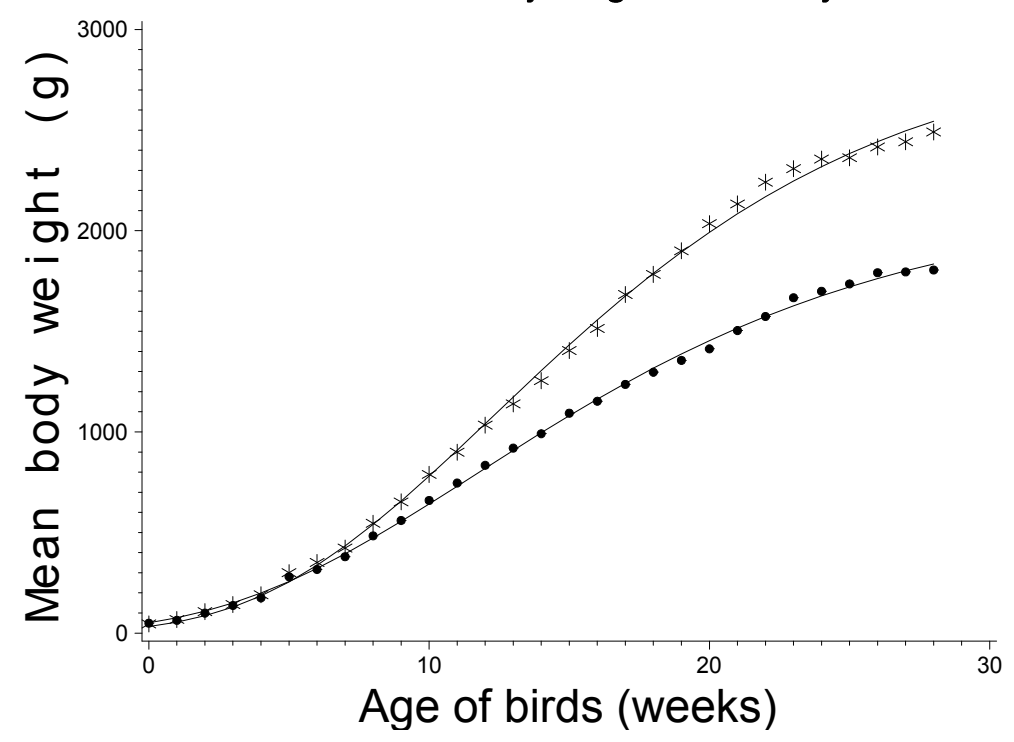

Figure 1d. 


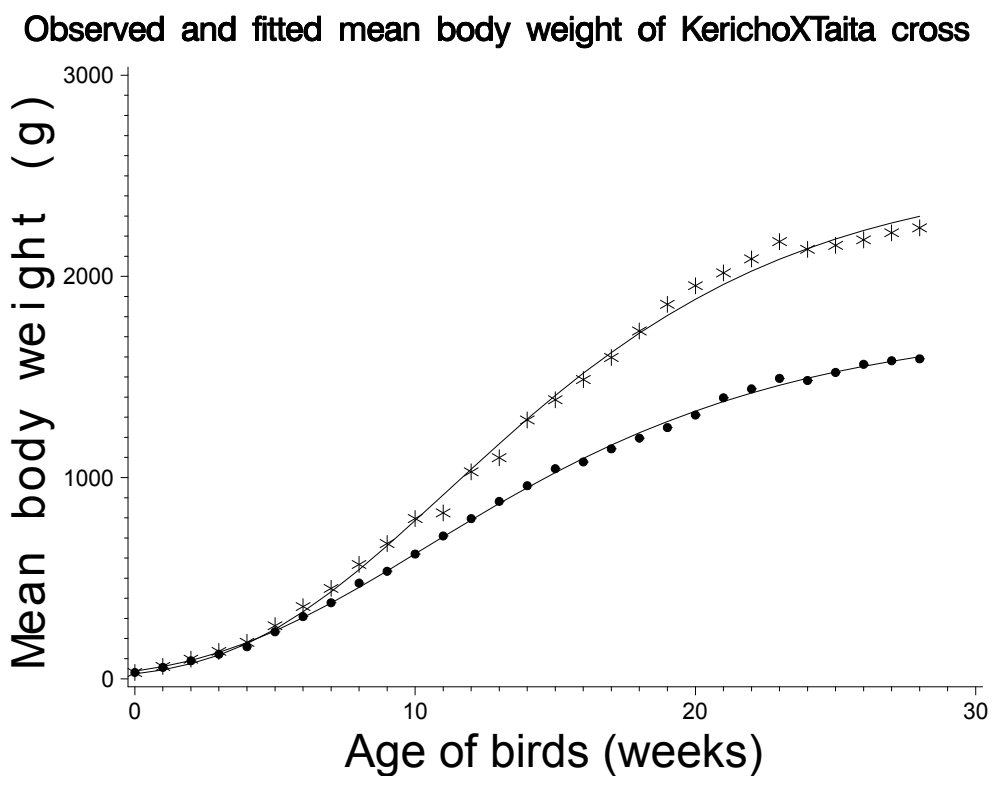

Figure 1e.

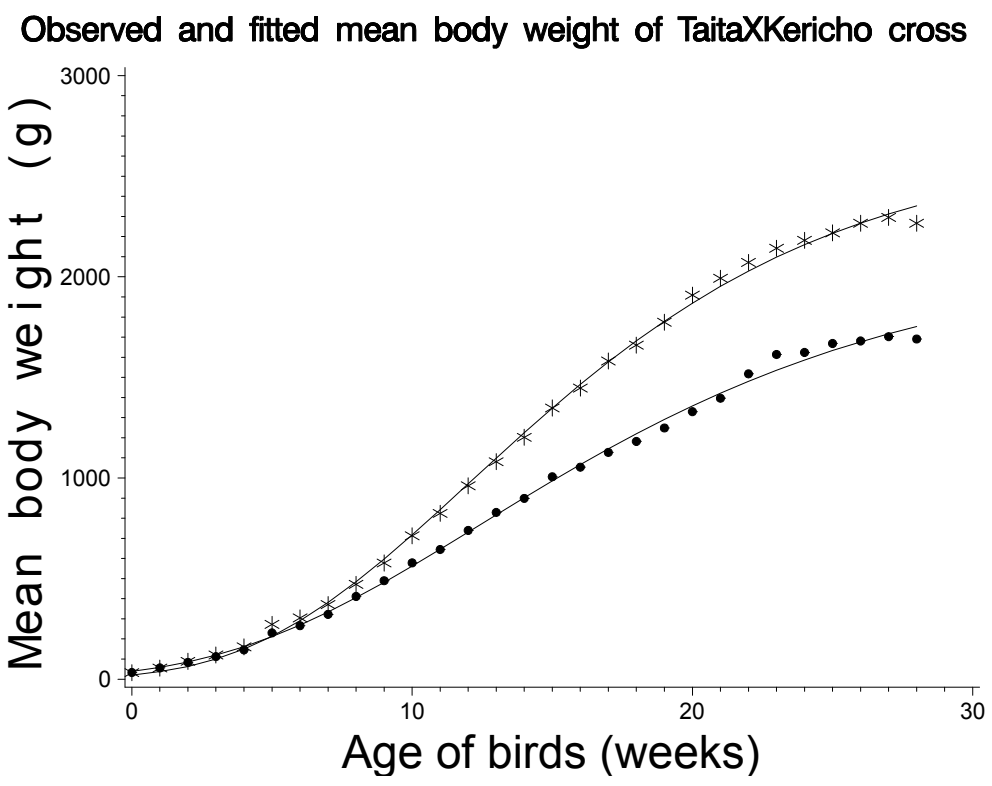

Figure 1f.

Figure 1. Observed and predicted weight plotted against week of age of male $(*)$ and female $(\bullet)($ a) Nyeri*Kericho, (b) Kericho*Nyeri, (c) Nyeri*Taita, (d) Taita*Nyeri, (e) Kericho*Taita and (f) Taita*Kericho reciprocal crosses 
Fitted log mean weight of six reciprocal crosses of male indigenous chicken

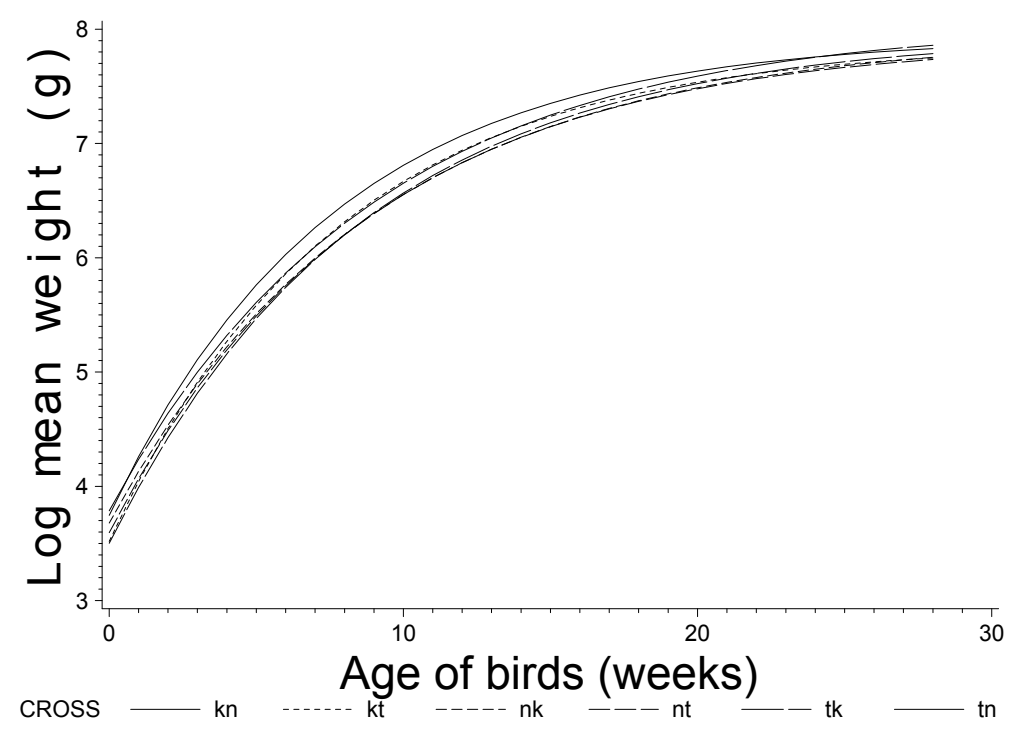

Figure 2a.

Fitted log mean weight of six reciprocal crosses of female indigenous chicken

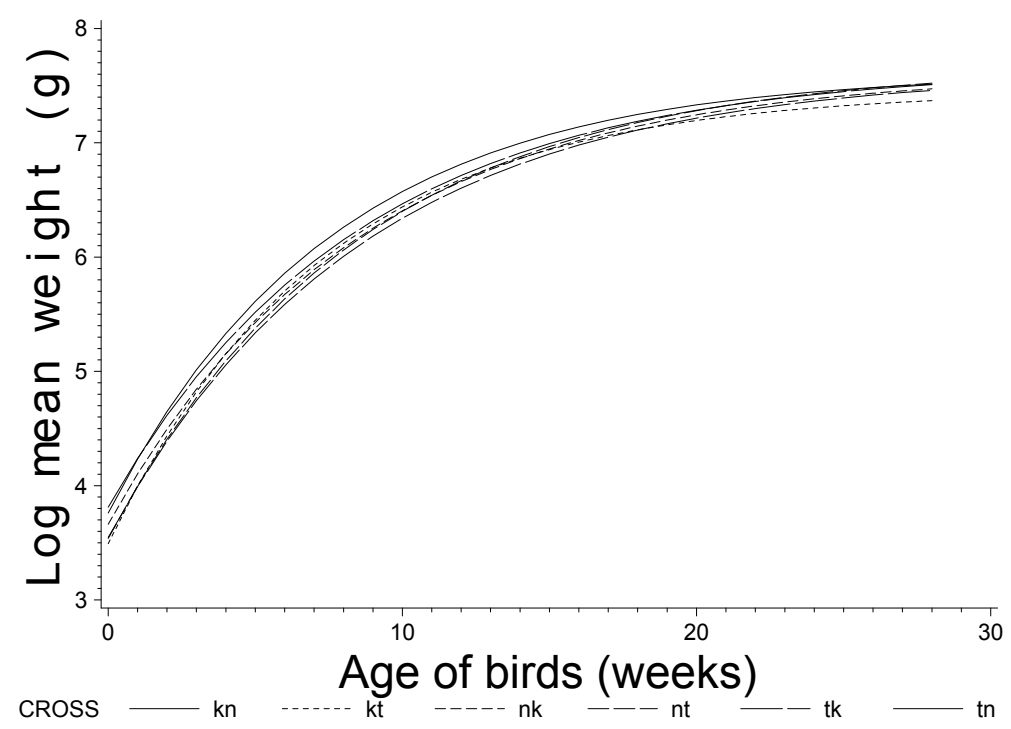

Figure 2b.

Figure 2. Plots of log of mean weights against weeks of age of individual crosses for the (a) male (b) female birds 